\title{
LONG-TERM INTRAMUSCULAR PREDNISOLONE THERAPY
}

\author{
BY \\ H. F. WEST* \\ Sheffield Centre for the Investigation and Treatment of Rheumatic Diseases
}

In a previous report on the use of the intramuscular route for prednisolone therapy (West, 1958), an account was given of sixteen patients treated by weekly depot injections of prednisolone acetate (Pfizer's Deltacortril suspension) for periods of from 4 to 11 months. The present report is of sixteen patients treated similarly for from 1 to $3 \frac{1}{2}$ years (mean $2 \frac{1}{2}$ ). The object for the study was to find out whether prednisolone administered via the systemic circulation would, in the long run, result in the same complications as attend its administration via the portal circulation. When corticosteroids are administered by mouth, high concentrations pass through the intestinal wall and through the liver. Does this give rise to complications or adaptations that the intramuscular route would avoid?

\section{Subjects and Methods}

Of the sixteen patients, eight were male and eight female. Their mean age was 47 years (range 20 to 58). Fifteen had rheumatoid arthritis and one ankylosing spondylitis. Three were included because they had hepatomegaly due to amyloidosis, and two of these had had gastric haemorrhages. Four were included because they had peptic ulcers, and three of these had bled. Of six patients who had not previously received corticosteroid therapy, three had widespread rheumatoid arthritis of less than one year's duration; the mean duration of disease in all the others was 7 years. At the start of the intramuscular therapy the mean erythrocyte sedimentation rate for the sixteen patients was $36 \mathrm{~mm}$. $/ \mathrm{hr}$ (Wintrobe).

Injections were given weekly and the usual assessments were made at least every 4 weeks. At the start of the study, 4 years ago, it was thought that the prednisolone acetate would be less effective given intramuscularly, so that the early doses were excessive (100 to $125 \mathrm{mg}$. per week). It was soon found that the steroid was at least as effective, mg. for mg., by this route as by the oral

* Physician-in-charge and Part-time member of the external staff of the Medical Research Council. route, and the doses were then reduced and new patients were started on 62.5 to $75 \mathrm{mg}$. per week. (The effectiveness has to be assessed over a period of some months, since each week the clinical response is better in the first few days after the injection than it is towards the end of the week.) During the second year of the study a number of attempts were made to use more concentrated suspensions of prednisolone acetate and prednisolone trimethylacetate, in the hope of prolonging the intervals between injections, but the results were not satisfactory.

\section{Results}

(1) Adaptation.-It is well known that the major remission of symptoms which is enjoyed by most patients severely affected by rheumatoid arthritis, when they start taking $10 \mathrm{mg}$. prednisolone daily, is not maintained for very long. Objectively, too, the advantage of the patients over the controls can be seen to diminish slowly over the years. This was well shown in the Medical Research CouncilNuffield Foundation Trial (Joint Committee, 1960). It is the author's impression that this adaptation does not occur, or is less apparent, during long-term corticotropin therapy, in which the corticosteroid (from the adrenal) enters the systemic circulation. It was hoped, therefore, that little or no adaptation would follow intramuscular prednisolone therapy. Unfortunately, clinical adaptation, a failure to maintain the initial subjective and objective benefit, did occur in five of the six patients who had not previously received corticosteroid therapy. The sixth patient, however, almost fully recovered and was able to discontinue therapy.

(2) Weight Gain.-The changes in weight, observed monthly, were such as one would have expected to see with oral therapy.

(3) Blood Pressure.-At the start of the intramuscular therapy, six patients had diastolic pressures of $90 \mathrm{~mm}$. $\mathrm{Hg}$ or more. At the end this number had 
risen to ten, as it might well have done from continued oral therapy at the same dose level.

(4) Amyloid Formation.-Two patients developed hepatomegaly during intramuscular therapy and in the Congo red test 100 per cent. of the dye was absorbed. Of the three who already had this condition, one remained improved during 3 years' therapy, but still had hepatomegaly, one died suddenly of amyloidosis after 2 years' therapy (no cause for death other than gross widespread amyloidosis was found at autopsy), and the third died of cerebral haemorrhage at the age of 42 , after 2 years' therapy with no evidence of a reduction in the size of his liver.

(5) Peptic Ulceration.-No patient developed symptoms of peptic ulceration for the first time during the intramuscular therapy. Of the three patients who had bled previously, one had a very large chronic ulcer which bled again, and he had a partial gastrectomy. The second developed a large amyloid liver and bled again, but had dyspeptic symptoms only when he took aspirin. The third was changed from oral to intramuscular therapy shortly after a gastric haemorrhage and has had no ulcer symptoms since ( $3 \frac{1}{2}$ years). The fourth had had ulcer symptoms on and off for 10 years and continued to have them during $2 \frac{1}{2}$ years of intramuscular therapy; but this patient refused to stop smoking cigarettes and continued to take aspirincontaining analgesics on an empty stomach.

(6) Pathological Bruising.-This complication, which occurs when prednisolone, or some of its analogues, are given continuously for several years, was equally apparent during intramuscular therapy.

(7) Hypercortisonism. - It is common for rheumatoid arthritic women, who are treated for many years with prednisolone $(7 \cdot 5-10 \mathrm{mg}$. daily) during or after the menopause, to complain of the following symptoms: They wake free from stiffness and set out to do some housework, but rapidly tire and have to rest. The little work they do brings on stiffness, whereas formerly it used to relieve it. They are irritable for no reason, complain of generalized tenderness, and easily dissolve into tears. This symptom-complex has been referred to as "hypercortisonism" by physicians at the Mayo Clinic. No evidence was found to suggest that intramuscular therapy either relieved it or prevented its occurrence.

\section{Discussion}

When prednisolone is given by mouth, the liver receives a higher concentration of the hormone than when it is given by intramuscular injection (as acetate), since the oral absorption is fast and the intramuscular is slow. The liver may also receive $a \Rightarrow$ greater total dose, since some prednisolone is meta- $\stackrel{\vec{P}}{+}$ bolized to inactive prednisone elsewhere in the body을 (unpublished observations) and there will be more $\overline{\bar{\sigma}}$. time for this to happen if the hormone is given $\frac{\omega}{\sigma}$ intramuscularly. Although the liver is able to $\varrho$ metabolize prednisolone and is able to reduce $\%$ prednisone back to prednisolone (which it does very $\vec{\circ}$ much more efficiently), it is possible that some of the unwanted effects of corticosteroid therapy may stem $\vec{\omega}$ from altered liver metabolism. It was with these thoughts in mind that the present study was made. The results were uniformly disappointing andis nothing can be said in mitigation save perhaps in the $\vec{\sim}$ case of peptic ulceration. It is hardly to be expected $\vec{c}$ that the change from oral to intramuscular pred- $\underline{\theta}$ nisolone will cure a chronic peptic ulcer. The $\frac{}{5}$ impression gained is that the change is one way of reducing the likelihood of peptic ulceration, and that $c$ it may be of real value, at least as a temporary $\vec{\varnothing}$ measure, in severe gastric and gastro-intestinal $\vec{\bullet}$ disturbances.

A case may be made for the intramuscular route for patients who need prednisolone but who cannoto be relied upon to take it regularly by mouth. In such cases one would know when a dose had been missed and several days would elapse before the $\frac{0}{8}$ depot was exhausted. Similarly, an accident or $\cong$ medical emergency would not have to be accom- $\overrightarrow{\overrightarrow{0}}$ panied by sudden withdrawal of therapy. The 3 complication peculiar to intramuscular therapy is the development of a large relatively painless abscess at the injection site, but this can be avoided if the injections are given by a nurse who is aware of the necessity for a faultless technique.

\section{Summary and Conclusions}

Sixteen patients were treated with weekly intra-o muscular depot injections of prednisolone acetate for from 1 to $3 \frac{1}{2}$ years (mean $2 \frac{1}{2}$ ). Throughout thiso time they were closely observed to see whether any advantage would accrue from this avoidance of the $O$ oral route (i.e. the entry of the prednisolone via the N alimentary tract and portal circulation). No advan- N tage was demonstrated in respect of adaptation to therapy, tendency to weight gain, tendency to hypertension, pathological bruising, or liver amyloidosis. The observations did not exclude somes? benefit in respect of peptic ulceration, but it was 0 concluded, as an impression, that the change fromo oral to intramuscular prednisolone therapy was of real value only at times of severe gastric or gastro- $\overrightarrow{\mathbb{D}}$ intestinal disturbance. 
Thanks are due to the medical and nursing staff of this Centre, and to the patients for their willing co-operation. During the period of this study the author held a parttime Nuffield Research Fellowship of the University of Sheffield.

\section{REFERENCES}

Joint Committee of the Medical Research Council and Nuffield Foundation on Clinical Trials of Cortisone, ACTH, and Other Therapeutic Measures in Chronic Rheumatic Diseases (1960). Ann. rheum. Dis., 19, 331.

West, H. F. (1958). Ibid., 17, 273.

\section{Traitement prolongé par la prednisolone par voie intramusculaire}

\section{RÉSUMÉ}

On traita seize malades par des injections intramusculaires "dépôt" d'acétate de prednisolone une fois par semaine pendant 1 à 3 ans et demi ( $2 \frac{1}{2}$ en moyenne). Pendant ce temps ils furent soumis à une surveillance étroite pour déterminer si le fait d'éviter la voie orale présentait un avantage quelconque (c'est-à-dire le fait d'eviter le passage par la tube digestif et la circulation portale). On n'observa aucun avantage en ce qui concerne l'adaptation à la thérapie, tendance à prendre du poids, tendance à l'hypertension, des ecchymoses excessives ou l'amyloïdose hépatique. L'observation n'exclut pas un certain avantage en ce qui concerne l'ulcération peptique, mais on conclut, rien qu'une impression, que le changement de la thérapie orale à l'intramusculaire par la prednisolone ne fut vraiment utile qu'au cours de graves désordres gastriques ou gastro-intestinaux.

\section{Tratamiento prolongado con prednisolona por vía intramuscular}

\section{Sumario}

Dieciseis enfermos fueron tratados con inyecciones intramusculares "dépôt" semanales de acetato de prednisolona durante 1 a $3 \frac{1}{2}$ años (término medio $2 \frac{1}{2}$ ). Durante este tiempo fueron estrechamente observados para determinar si alguna ventaja podía añadirse a esta de evitar la vía oral (tal como la entrada de la prednisolona a través del tracto intestinal y de la circulación portal). No fué demostrada ninguna ventaja en relación con adaptación a la terapéutica, tendencia al aumento de peso, tendencia a la hipertensión, excesivos equimosis o amiloidosis hepática. Las observaciones no excluyeron cierto beneficio con relación a la ulceración péptica, pero se concluyó, como una impresión, que el cambio de la oral a la terapéutica intramuscular con prednisolona era de auténtico valor solamente en episodios de graves gástricos o gastro-intestinales disturbios. 